\title{
Seroprevalence of Hepatitis B Virus using HBV-5 Rapid Panel Test and Associated Factors amongst Pregnant Women Attending Antenatal Care in Garoua, North-Cameroon
}

\author{
Christian Ngounouh Taheu, Philippe Salomon Nguwoh, Ahie Demtaley, \\ Patrice Zanga Olinga, Joseph Fokam
}

\section{ABSTRACT}

Background: In Cameroon, prevalence of Hepatitis B Virus (HBV) is high and varies from different places in general population and vulnerable persons such as pregnant women. We performed this survey to determine seroprevalence of $\mathrm{HBV}$ using $\mathrm{HBV}-5$ Rapid panel test and associated factors amongst pregnant women attending antenatal care (ANC) in Garoua.

Methods: This was a cross-sectional study conducted from February, $15^{\text {th }}$ to April, 15 ${ }^{\text {th }}, 2016$ amongst 102 pregnant women attending ANC in city of Garoua. Data were obtained using a structured questionnaire by interview. The blood samples were collected and tested by the immunochromatographic panel method (OnSite HBV-5 Rapid Panel Test) for the detection of HBV biomarkers. Statistical analyses were performed by EPI Info $^{\mathrm{TM}}$ version 7 software, with $\mathrm{P}<0.05$ considered significant.

Results: Overall seroprevalence of HBV (HBsAg) was $10.78 \%(11 / 102)$ and the other HBV biomarkers were $15.68 \%(16 / 102), 9.80(10 / 102)$ and $26.47 \%(27 / 102)$ for anti-HBsAb, anti-HBeAb and total anti-HBcAb respectively. According to general information, marital status $(P=0.001)$ was statistically associated with $\mathrm{HBsAg}$ seroprevalence. Bivariate analysis logistic regression recorded that, scarification $(\mathrm{OR}=30.10 ; 95 \%$ CI 6.55 138.15; $\mathrm{P}=0.00000)$ and piercing or tattoo $(\mathrm{OR}=11.80 ; 95 \%$ CI $2.77-50.18$; $\mathbf{P}=\mathbf{0 . 0 0 0 0 8}$ ) were statistically associated with seroprevalence of $\mathrm{HBsAg}$.

Conclusion: Seroprevalence of $\mathrm{HBV}$ biomarkers is high amongst pregnant women attending ANC in Garoua. Associated factors such as scarification and piercing or tattoo were associated with $\mathrm{HBV}$ infection. The awareness of pregnant women about vaccination in routine against $\mathrm{HBV}$ were necessary to prevent the transmission of Mother-to-Child Transmission (MTCT).

Keywords: Associated factors, Garoua, HBV, pregnant women, seroprevalence
Submitted : November 17, 2021

Published : February 23, 2022

ISSN: $2593-8339$

DOI: $10.24018 /$ ejmed.2022.4.1.1147

\section{N. Taheu*}

Higher Institute of Sciences and Techniques Applied to Health, University of Douala, Yaoundé, Cameroon.

(e-mail: taheuchristian@gmail.com) P. S. Nguwoh

National Public Health Laboratory, Yaoundé, Cameroon.

(e-mail:

philippesalomonguwoh@gmail.com) A. Demtaley

Specialized Center for Medical Analysis

Techniques, Yaoundé, Cameroon.

(e-mail: demtaleyahie@yahoo.fr)

P. Z. Olinga

Distant Production House University, Delaware, United State of America.

(e-mail: patzanga100@gmail.com)

J. Fokam

Faculty of Health Sciences, University of Buea, Buea, Cameroon.

(e-mail: josephfokam@gmail.com)

*Corresponding Author

\section{INTRODUCTION}

HBV is an important worldwide public health problem and known to cause chronic hepatitis with high risk of death subsequent after cirrhosis and primary liver cancer. An estimated in 2015, 257 million persons were living with chronic HBV infection worldwide [1]-[3]. The widespread caused by HBV affects typically African and Western pacific areas with more than $68 \%$ of those infected in the world [2], [4]. Amongst African areas more affected by HBV infection, sub-Saharan Africa (SSA) has the second largest global weight of chronic carriers of HBV infection after Asian continent [5]. Greatest of the load of disease from HBV infection comes from infections acquired before, during or after birth. Then babies born to untreated HBV-infected mothers can acquire infection from the mother, commonly during birth [6]. Well-known, transmission from mother to its child or horizontal transmission in youthful remain a principal route of transmission mostly found in high endemic area of HBV like SSA [6]. Therefore, several pregnant women living in SSA are infected with or exposed to HBV that can be transmitted vertically to its new-borns [7]. Thus, babies born to mothers who are positive for both HBsAg and hepatitis $\mathrm{B}$ e antigen $(\mathrm{HBeAg})$ are at a higher risk of acquiring infection (transmission risk for $\mathrm{HBsAg}$-positive and $\mathrm{HBeAg}-$ positive mothers: $70-100 \%$ in Asia and $40 \%$ in Africa) than those born to HBsAg-positive mothers who have lost the HBeAg (5-30\% in Asia and 5\% in Africa) [8]-[10]. Moreover, $\mathrm{HBeAg}$-negative mothers have a near $0 \%$ risk of transmitting HBV to their offspring vaccinated at birth [11], 
whereas HBeAg-positive mothers have a $20 \%$ risk of transmitting the virus despite vaccination at birth [12]. Management of pregnant mothers with antivirals, which is being introduced as a new intervention to prevent mother-tochild transmission (MTCT) of HBV, should more reduce the risks of transmission [13].

Nevertheless, of whether they have been beforehand tested or immunized, screening of all pregnant women for HBV infection at the primary antenatal care appointment is imperative in understanding of the morbidity and mortality of pregnant women, its upshot on the gravidity result, and the risk of vertical transmission from mother to child [14]. HBsAg is the first detectable serological marker to appear in acute $\mathrm{HBV}$ infection. It is most commonly used in laboratory to screen for the presence of $\mathrm{HBV}$ infection and its perseverance for further than 6 months suggests chronic infection. Nonetheless, early in an infection, this antigen may not be present, and it may be undetectable later in the infection as it is being cleared by the host [15].

In Cameroon, the prevalence of $\mathrm{HBV}$ (HBsAg) varies according to regions and ethnic groups with an average estimated more than $8 \%$ (HBsAg $>8 \%$ ) [5], [16] like many countries situated in SSA. Several studies conducted by Noubiap and collaborators [17] in far north, Frambo and collaborators [18] in health district of Buea and Fomulu and collaborators [19] in Yaoundé found a prevalence of HBsAg of $10.20 \%, 9.7 \%$ and $7.7 \%$ respectively in pregnant women. The previous studies carried out in Cameroon found only the prevalence of HBsAg among pregnant women. Despite the variability of this prevalence (HBsAg), there is a rareness information concerning the HBV biomarkers. There are five serological biomarkers for $\mathrm{HBV}$ (HBsAg, anti-HBsAb, $\mathrm{HBeAg}$, anti-HBeAb, anti-HBcAb) that can be used to screen, diagnose, manage, and monitor HBV infection. In view of the above, it is therefore rational to conducted new investigation in a context of high endemicity like Cameroon. The survey was designed to determine seroprevalence and associated factors of $\mathrm{HBV}$ amongst pregnant women attending ANC in Garoua using HBV-5 Rapid panel test.

\section{Methodology}

\section{A. Study Design and Sitting}

During February, $15^{\text {th }}$ to April, $15^{\text {th }}$ 2016, a multicenter cross-sectional study was carried out amongst pregnant women attending ANC at the regional hospital and 03 health Integrated centers (Kollere, Foulbere and Souari) of Garoua, in far North of Cameroon.

\section{B. Ethical Considerations}

The ethical clearance for this study was issued from the National Ethics Committee of Research on Human Health of Cameroon (Reference: N²016/04/333/CE/CNERSH/SP). Administrative authorizations were obtained from the Regional Delegation of Public Health for the North Region (Reference: $\mathrm{N}^{\circ} 0491 \mathrm{NS} / \mathrm{SG} / \mathrm{DRSPN} / \mathrm{SAGE} / \mathrm{GRA}$ ) and the director of Garoua regional hospital. All participant received detailed information with an information sheet. Furthermore, all was signed written inform consent approved by the National Ethics Committee. Each participant was identified by a single code to guarantee the confidentiality.

\section{Sample Size Determination}

We obtained sample size using the following formula: $\mathrm{n}=$ $\mathrm{z}^{2} \mathrm{xPQ} / \mathrm{E}^{2}$ with " $\mathrm{z} "=1.645(90 \%$ confidence interval), "P"= prevalence of HBV (HBsAg) found in Cameroon (10.20\%) [17]., "Q" = 1-P and $\mathrm{E}=$ random error $(5 \%)$. We obtained a minimum size $\mathrm{n}$ of $97.88 \approx 98$ participants but 102 were enrolled. Participants were recruited consecutively by interview with a structured questionnaire including general data such as age group, marital status, education level, occupation, gestational age, parity, history of blood transfusion, scarification, piercing or tattoo, previous surgery and knowledge of the disease.

\section{Sample Collection and Detection of HBV Biomarkers}

Five milliliters of blood were collected at the bend of the elbow in the dry tube previously labeled using a vacutainer needle. After centrifugation of whole blood, sera obtained were separated in the cryotubes previously labeled and stored at $-20^{\circ}$ in the freezer. The samples were analyzed by the "OnSite HBV Rapid Panel Test" kit (from the CTK Biotech USA laboratory; Lot No F0624K7D00, date of manufacture: 10-08-2015 and expiration date: 09-02-2017) according to the manufacturer's instructions.

OnSite HBV Rapid Panel Test is the lateral flow chromatographic immunoassay consisting of 5 test panel strips for the qualitative detection of $\mathrm{HBsAg}$, HBsAb, $\mathrm{HBeAg}, \mathrm{HBeAb}$, and $\mathrm{HBcAb}$ assembled in one cassette. Each strip of the panel member is composed of a sample pad, colloid gold conjugate pad, nitrocellulose membrane (NC membrane) strip pre-coated with control band ( $\mathrm{C}$ band) and test band ( $\mathrm{T}$ band), and absorbent pad. The HBeAg, HBsAb, $\mathrm{HBsAg}$ are based sandwich immunoassay and the HBeAb, $\mathrm{HBcAb}$ are based competitive immunoassay [20]. Negative result shows the appearance of one red line only in control zone " $\mathrm{C}$ " on the HBsAg, HBsAb, HBeAg strip, or both the " $C$ " and the " $T$ " lines are developed on either the HBeAb or the $\mathrm{HBcAb}$ strip. The positive result was reported two distinct red lines appear in the "C" and the "T" on the HBsAg, $\mathrm{HBsAb}$, or the HBeAg strip or only the " $\mathrm{C}$ " line is developed on the $\mathrm{HBeAb}$ or the $\mathrm{HBcAb}$ strip.

\section{E. Data Collection and Statistics}

Data collected by a questionnaire and the results obtained after analysis of the samples were reported in a MS excel spreadsheet. Then transported into, and analysed with, EPI Info $^{\mathrm{TM}}$ software version 7. Statistical association between HBV biomarkers, pregnant women characteristics and associated factors were performed using chi-square, Fisher's exact test corrected by Yates test and bivariate logistic regression. $\mathrm{P}$-values were significant for all $\mathrm{P}<0.05$.

\section{F. Study Limitations}

Some limitations were described in this present study: The type Rapid Diagnostic Test (RDT) used to detect HBV biomarkers in the collected sera. Furthermore, the lack of HBV-DNA PCR assay did not allow us to determine the contribution of occult HBV infection (OBI) on the epidemiological burden of $\mathrm{HBV}$ during gravidity in this locality. Moreover, the small sample size did not allow us to have roughly statistically significant results due to the lack of financial resources. 


\section{RESULtS}

A. General Information of the Participants TABLE I: GENERAL INFORMATION OF PARTICIPANTS

\begin{tabular}{|c|c|c|}
\hline Variables & $\begin{array}{l}\text { Total number of participants } \\
\qquad \mathrm{N}=102\end{array}$ & Frequency $(\%)$ \\
\hline \multicolumn{3}{|c|}{ Age groups (in years) } \\
\hline $15-24$ & 47 & 46.08 \\
\hline $25-34$ & 52 & 50.98 \\
\hline $35-44$ & 03 & 02.94 \\
\hline \multicolumn{3}{|c|}{ Marital Status } \\
\hline Married & 94 & 92.15 \\
\hline Single & 08 & 07.85 \\
\hline \multicolumn{3}{|c|}{ Education level } \\
\hline Primary & 88 & 86.27 \\
\hline Secondary & 03 & 02.94 \\
\hline University & 11 & 10.79 \\
\hline \multicolumn{3}{|c|}{ Occupation } \\
\hline Pupils & 02 & 01.96 \\
\hline Students & 08 & 07.85 \\
\hline Housewives & 85 & 83.33 \\
\hline Trade & 02 & 01.96 \\
\hline Seamstress & 02 & 01.96 \\
\hline Nurses & 03 & 02.94 \\
\hline \multicolumn{3}{|c|}{ Gestational age } \\
\hline First Trimestre & 23 & 22.55 \\
\hline Second Trimestre & 49 & 48.04 \\
\hline Third Trimestre & 30 & 29.41 \\
\hline \multicolumn{3}{|c|}{ Parity } \\
\hline Primiparous & 24 & 23.53 \\
\hline Pauciparous & 32 & 31.37 \\
\hline Multiparous & 46 & 45.10 \\
\hline
\end{tabular}

Out of one hundred and thirty-five (135) pregnant women were met but only one hundred and two (102) approved to participate with the participation rate of $75.55 \%(102 / 135)$. The average age of the pregnant women was $24.11 \pm 5.56$ years (minimum: 15 years and maximum: 44 years). The predominant age group was 25-34 years with $50.98 \%(n=52)$, followed by $15-24$ years old with $46.08 \%(n=47)$ and pregnant woman aged between $35-44$ years with only $2.94 \%$ $(\mathrm{n}=3)$. Among one hundred and two (102) pregnant women recruited, $92.15 \%(n=94)$ were married and only $7.85 \%(n=8)$ were single. Eighty-eight $(86.27 \%)$ study participants were primary education level, $83.33 \%(\mathrm{n}=85)$ were housewives, forty-nine $(48.04 \%)$ were secondary gestational age, and forty-six (45.10\%) were multiparous.

\section{B. Seroprevalence of HBV Biomarkers}

Among one hundred and two pregnant women tested, seroprevalence of HBV were $10.78 \%(\mathrm{n}=11$; $95 \% \mathrm{CI}$ : 5.51 18.48), 15.68\% ( $\mathrm{n}=16 ; 95 \% \mathrm{IC}: 6.78 \%$ - 27.58\%), 9.80\% $(\mathrm{n}=10 ; 95 \% \mathrm{IC}: 2.52 \%-17.08 \%), 26.47 \%(\mathrm{n}=27 ; 95 \% \mathrm{IC}$ : $15.67 \%$ - 37.27\%) for HBsAg, anti-HBs antibodies (anti$\mathrm{HBs} \mathrm{Ab}$ ), anti-HBe antibodies (anti-HBeAb) and total anti$\mathrm{HBc}$ antibodies (anti-HBcAb) respectively. Moreover, no HBeAg was found in the current study (Fig. 1).

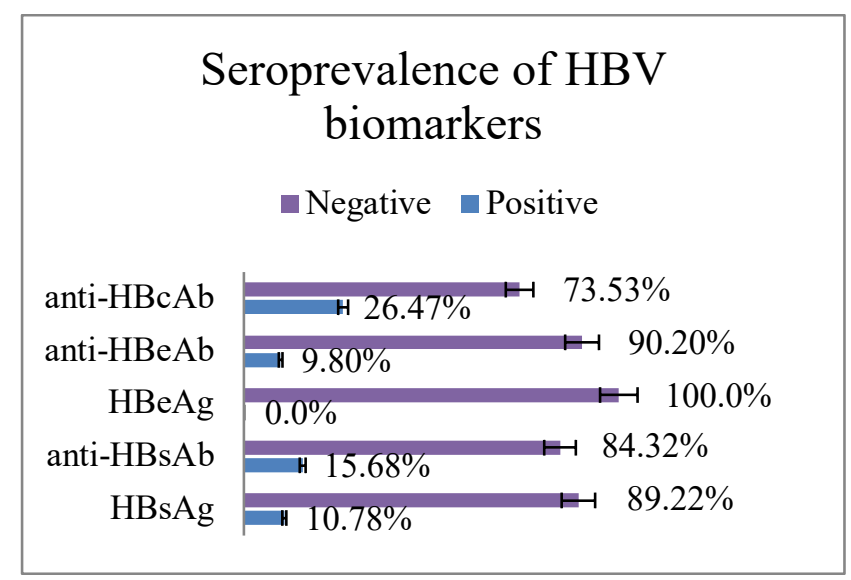

Fig. 1. Seroprevalence of Hepatitis B Virus biomarkers.

TABLE II: GENERAL INFORMATION OF PARTICIPANTS ASSOCIATED TO HBV BIOMARKERS

\begin{tabular}{|c|c|c|c|c|c|c|c|c|c|}
\hline \multirow[b]{2}{*}{ Variables } & \multirow{2}{*}{$\begin{array}{c}\text { Total } \\
\mathrm{N}=102\end{array}$} & HBsAg & \multirow[b]{2}{*}{ P-Value } & \multirow{2}{*}{$\begin{array}{c}\text { Anti-HBsAb } \\
\text { Positive } 16 \\
(\%) \\
\end{array}$} & \multirow[b]{2}{*}{ P-Value } & \multirow{2}{*}{$\begin{array}{c}\text { Anti-HBeAb } \\
\text { Positive } \\
10(\%) \\
\end{array}$} & \multirow[b]{2}{*}{ P-Value } & \multirow{2}{*}{$\begin{array}{c}\text { Anti-HBcAb } \\
\text { Positive } 27 \\
(\%)\end{array}$} & \multirow[b]{2}{*}{ P-Value } \\
\hline & & $\begin{array}{c}\text { Positive } \\
11(\%) \\
\end{array}$ & & & & & & & \\
\hline \multicolumn{10}{|c|}{ Age groups (in years) } \\
\hline $15-24$ & 47 & $04(8.51)$ & \multirow{3}{*}{0.91} & $07(14.89)$ & \multirow[t]{3}{*}{0.96} & $04(8,51)$ & \multirow[t]{3}{*}{0,95} & $10(21.27)$ & \multirow[t]{3}{*}{0,58} \\
\hline $25-34$ & 52 & $06(11.54)$ & & $09(17.64)$ & & $06(11.76)$ & & $16(31.37)$ & \\
\hline $35-44$ & 03 & $01(33.33)$ & & $0(0.00)$ & & $0(0.00)$ & & $01(25.00)$ & \\
\hline \multicolumn{10}{|c|}{ Marital status } \\
\hline Married & 94 & $07(7.45)$ & \multirow{2}{*}{0.001} & 14 (14.89) & \multirow[t]{2}{*}{0.80} & $06(6.38)$ & \multirow[t]{2}{*}{0.0007} & $23(24.46)$ & \multirow[t]{2}{*}{0.24} \\
\hline Single & 08 & $04(50.0)$ & & $02(25.00)$ & & $04(50.00)$ & & $04(50.00)$ & \\
\hline \multicolumn{10}{|c|}{ Education level } \\
\hline Primary & 88 & $11(12.50)$ & \multirow{3}{*}{0.71} & $16(18.18)$ & \multirow[t]{3}{*}{0.52} & $10(11.36)$ & \multirow[t]{3}{*}{0,74} & $25(28.40)$ & \multirow[t]{3}{*}{0.16} \\
\hline Secondary & 03 & $0(0.00)$ & & $0(0.00)$ & & $0(0.00)$ & & $02(6.67)$ & \\
\hline University & 11 & $0(0.00)$ & & $0(0.00)$ & & $0(0.00)$ & & $0(0.00)$ & \\
\hline \multicolumn{10}{|c|}{ Occupation } \\
\hline Pupils & 02 & $0(0.00)$ & \multirow{6}{*}{0.08} & $00(0.00)$ & \multirow[t]{6}{*}{0.92} & $0(0.00)$ & \multirow[t]{6}{*}{0.05} & $02(100)$ & \multirow[t]{6}{*}{0.24} \\
\hline Student & 08 & $0(0.00)$ & & $0(0.00)$ & & $0(0.00)$ & & $0(0.00)$ & \\
\hline Housewives & 85 & $09(10.59)$ & & $16(18.82)$ & & $08(9.41)$ & & $23(27.05)$ & \\
\hline Trade & 02 & $02(100.0)$ & & $0(0.00)$ & & $02(100)$ & & $2(100)$ & \\
\hline Seamstress & 02 & $0(0.00)$ & & $0(0.00)$ & & $0(0.00)$ & & $0(0.00)$ & \\
\hline Nurses & 03 & $0(0.00)$ & & $0(0.00)$ & & $0(0.00)$ & & $0(0.00)$ & \\
\hline \multicolumn{10}{|c|}{$\begin{array}{l}\text { Gestational age } \\
\end{array}$} \\
\hline First Trimestre & 23 & $01(4.35)$ & 0.51 & $02(8.66)$ & 0.006 & $0(0.00)$ & 0.13 & $03(13.04)$ & 0.08 \\
\hline Second Trimestre & 49 & $06(12.25)$ & & $14(28.57)$ & & $04(8.16)$ & & $12(24.48)$ & \\
\hline Third Trimestre & 30 & $04(13.33)$ & & $0(0.00)$ & & $06(20.00)$ & & $12(40.00)$ & \\
\hline & & & & Parity & & & & & \\
\hline Primiparous & 24 & $0(0.00)$ & & $02(8.33)$ & 0.66 & $0(0.00)$ & 0.13 & $04(16.66)$ & 0.34 \\
\hline Pauciparous & 32 & $02(6.25)$ & 0.08 & $05(15.62)$ & & $02(6.25)$ & & $08(25.00)$ & \\
\hline Multiparous & 46 & $09(19.56)$ & & $09(19.56)$ & & $08(17.39)$ & & $15(32.60)$ & \\
\hline
\end{tabular}

$\%$ : Frequency 
TABLE III: FACTORS ASSOCIATED AND SEROPREVALENCE OF HBV BIOMARKERS

\begin{tabular}{|c|c|c|c|c|c|c|c|c|c|}
\hline \multirow{2}{*}{ Variables } & \multirow{2}{*}{ Total $\mathrm{N}=102$} & HBsAg & \multirow{2}{*}{ P-Value } & Anti-HBsAb & \multirow{2}{*}{ P-Value } & \multirow{2}{*}{$\begin{array}{c}\text { Anti- } \\
\text { HBeAb } \\
\text { Positive } 10 \\
(\%)\end{array}$} & \multirow[t]{3}{*}{ P-value } & $\begin{array}{c}\text { Anti- } \\
\mathrm{HBcAb}\end{array}$ & \multirow{3}{*}{ P-Value } \\
\hline & & $\begin{array}{c}\text { Positive } \\
11(\%)\end{array}$ & & $\begin{array}{c}\text { Positive } 16 \\
(\%)\end{array}$ & & & & $\begin{array}{c}\text { Positive } 27 \\
(\%)\end{array}$ & \\
\hline \multicolumn{8}{|c|}{ History of Blood Transfusion } & & \\
\hline Yes & 0 & $0(0.00)$ & \multirow{2}{*}{0,87} & $0(0.00)$ & \multirow[t]{2}{*}{0.89} & $0(0.00)$ & \multirow[t]{2}{*}{0.86} & $0(0.00)$ & \multirow[t]{2}{*}{0.90} \\
\hline No & 102 & $11(10.78)$ & & $16(15.68)$ & & $10(9.80)$ & & $27(26.47)$ & \\
\hline \multicolumn{10}{|c|}{ Scarification } \\
\hline Yes & 12 & $07(58.33)$ & \multirow{2}{*}{0.00000} & $0(0.00)$ & \multirow[t]{2}{*}{0.24} & $6(50.00)$ & \multirow[t]{2}{*}{$\begin{array}{c}0.0000 \\
7\end{array}$} & $10(83.33)$ & \multirow[t]{2}{*}{0.00001} \\
\hline No & 90 & $04(4.44)$ & & $16(17.78)$ & & $4(4.44)$ & & $17(18.89)$ & \\
\hline \multicolumn{10}{|c|}{ Piercing or Tattoo } \\
\hline Yes & 11 & $05(45.45)$ & \multirow{2}{*}{0.00008} & $4(9.09)$ & \multirow[t]{2}{*}{0.11} & $3(27.27)$ & \multirow[t]{2}{*}{0.12} & $5(45.45)$ & \multirow[t]{2}{*}{0.25} \\
\hline No & 91 & $06(6.59)$ & & $12(13.19)$ & & $7(7.69)$ & & $22(24.18)$ & \\
\hline \multicolumn{10}{|c|}{ Previous Surgery } \\
\hline Yes & 09 & $0(0.00)$ & \multirow{2}{*}{0.59} & $1(9.09)$ & \multirow[t]{2}{*}{0.93} & $5(10.64)$ & \multirow[t]{2}{*}{0.65} & $2(18.18)$ & \multirow[t]{2}{*}{0.92} \\
\hline No & 93 & $11(11.83)$ & & $15(16.85)$ & & $5(9.09)$ & & $25(28.09)$ & \\
\hline \multicolumn{10}{|c|}{ Knowledge of the Disease } \\
\hline Yes & 47 & $03(6.38)$ & \multirow{2}{*}{0,87} & $8(14.55)$ & \multirow[t]{2}{*}{0.73} & $5(10.64)$ & \multirow[t]{2}{*}{0.79} & $7(14.89)$ & \multirow[t]{2}{*}{0.01} \\
\hline No & 55 & $08(14.55)$ & & $8(17.08)$ & & $5(9.09)$ & & $20(36.36)$ & \\
\hline
\end{tabular}

$\%$ : Frequency

\section{General Information of Participants Associated to HBV Biomarkers}

The overall seroprevalence of HBV (HBsAg) was 10.78\%. Among pregnant women HBsAg-positive, higher seroprevalence, $11.54 \%(6 / 52)$, was observed in age of $25-34$ years. The HBsAg seroprevalence of $7.45 \%$ (7/94) was recorded in married versus (vs.) $50.0 \%$ (4/8) in single pregnant women $(\mathrm{P}=0.001)$. HBsAg positive was only recorded in study participants with primary education level (12.50\%). Moreover, the highest seroprevalence of $10.59 \%$ $(9 / 85)$ was observed in housewives than other occupations $(\mathrm{P}=0.08)$ (TABLE II).

\section{Associated Factors and Seroprevalence of $H B V$}

In this study, bivariate logistic regression analysis shows that two variables (scarification and piercing) were significantly associated with seroprevalence of HBsAg. Pregnant women who had a scarification were more infected than pregnant women who had no scarification $(\mathrm{OR}=30.10$; $95 \%$ CI $6.55-138.15 ; \mathrm{P}=0.00000)$. In the other hand, the statistically significant association was recorded between study participants who had piercing or tattoo and those who had no piercing or tatoo $(\mathrm{OR}=11.80 ; 95 \% \mathrm{CI}$ 2.77-50.18; $\mathrm{P}=0.00008$ ) (TABLE III).

For the other HBV-biomarkers, scarification was significantly associated with anti-HBe antibodies and anti$\mathrm{HBc}$ antibodies. Six on twelve (50.00\%) study participants who had scarification vs $4.00 \%$ (4/90) who had no scarification were anti-HBeAb positive $(\mathrm{OR}=21.50 ; 95 \% \mathrm{CI}$ 4.74-97.50; $\mathrm{P}=0.00007)$. Ten on twelve $(83.3 \%)$ women with scarification vs $18.89 \%(17 / 90)$ without scarification were anti-HBcAb positive $(\mathrm{OR}=21.47$; $95 \% \mathrm{CI}$ 4.30-107.12; $\mathrm{P}=0.00001)$. Furthermore, we recorded higher seroprevalence of anti-HBc antibodies among women who did not know HBV seroprevalence with $36.36 \%$ (20/55) vs $14.89 \%$ (7/47) for those who know HBV disease $(\mathrm{P}=0.01)$.

\section{DISCUSSION}

The study was performed to determine prevalence of HBV using HBV-5 Rapid panel test and associated factors amongst pregnant women attending ANC in Garoua. A total of 102 pregnant women were recruited consecutively in this study with an average age of 24.11 years. Seroprevalence of $\mathrm{HBsAg}$ was $10.78 \%$ (95\%CI: $5.51-18.48)$. This is reasonably because several pregnant women enrolled were asymptomatic [19]. This result joins the prevalence of HBsAg in the high endemicity zone like SSA [21], [22]. Many studies conducted in Cameroon and SSA reported high prevalence of HBsAg among pregnant women [23]-[26] suggest that prevalence of HBsAg varies from place to place. The result obtained may explicated through small rate (15.68\% [16/102]) of pregnant women who were vaccinated (anti-HBsAb positive), the higher rate $(26.47 \%$ [27/102]) of those who have previous contact with hepatitis B virus (anti-HBcAb) and the knowledge about HBV-infection because fifty percent of study participants have no information about HBV. In the group of population who did not know disease, the higher seroprevalence of HBsAg was more observed $(14.55 \%$ [8/102]). This higher HBsAg seroprevalence could be also explained by a small sample size, a socioeconomic status and the diagnostic technique used (RDTs) [19], [27], [28].

Concerning characteristics of pregnant women, higher HBsAg seroprevalence was more recorded in those who aged 25 to 34 years $(11.54 \%)$. Similar findings were reported by [28] in Ethiopia who have observed the higher HBsAg prevalence amongst pregnant women aged 20 to 24 years and 25 to 29 years. The finding can have explicated by the fact that the age group associates with the uppermost age of sexual activity, signifying the role of sexual intercourse in HBV transmission [29]. HBsAg positive was only recorded in study participants with primary education level $(12.50 \%)$. Similar findings were recorded in preceding survey carried out by Manyahi and collaborators who show high HBsAg prevalence among participant with primary matched to secondary college level education [30]. Furthermore, marital status was statistically associated with the presence of $\mathrm{HBsAg}$ after bivariate testing $(\mathrm{P}=0.01)$. In this study, more than $90 \%$ 
of women were married and among them, 7.45\% (7/94) were HBsAg positive compared to $50.0 \%(04 / 8)$ in single pregnant women. The HBsAg prevalence was reported in the two studies conducted by Bayo and collaborators in Uganda and Tegegne and collaborators in Ethiopia who found 10.6\% and $2.64 \%$ respectively in pregnant women who were married [31], [32].

In this study, two variables (scarification and piercing or tattoo) were associated with HBsAg. Study participant with scarification had 30 times $(\mathrm{OR}=30.10 ; 95 \% \mathrm{CI}$ : 6.55-138.15; $\mathrm{P}<0.0001)$ high chance to contact the virus. In the other hand, women with piercing or tattoo had 12 times $(\mathrm{OR}=11.80 ; 95 \%$ CI: 2.77-50.18; $\mathrm{P}<0.0001)$ high chance to carried HBV. Comparable results were recorded by [28] in Eastern Ethiopia $(\mathrm{AOR}=8.9 ;$ 95\%CI: 1.3-59.39; $\mathrm{P}=0.025)$, Baye and collaborators [33] in Ethiopia (AOR $=18.1$; 95\%CI: 2.9-114; $\mathrm{P}=0.002)$ and $[34]$ in Northwest Ethiopia $(\mathrm{AOR}=3.0 ; 95 \% \mathrm{CI}$ : $1.17-7.80 ; \mathrm{P}=0.02)$ who recorded that piercing or tattoo was statistically associated with the HBV infection. Otherwise, the seroprevalence of HBsAg was not significantly related to the Knowledge about HBV. These could be explained by the small sample size.

\section{CONCLUSION}

The findings of this study reveal a high seroprevalence of HBV biomarkers amongst pregnant women in Garoua, North-Cameroon. The higher seroprevalence of HBsAg was more recorded in pregnant women in age group of 25-34 years, who were married and who were housewives' occupation. Associated factors such as scarification and piercing or tattoo were statistically associated with HBV infection.

\section{RECOMMENDATION}

The systematic screening of HBV using HBV-5 Rapid panel test and the awareness of pregnant women about vaccination in routine against $\mathrm{HBV}$ were necessary to prevent the transmission of Mother-to-Child Transmission (MTCT).

\section{ACKNOWLEDGEMENTS}

The authors would like to acknowledge the pregnant women who agreed to participate in the study. We would also thank the Regional Delegation of Public Health for the North Region and the director of Garoua regional hospital for the administration authorization.

\section{REFERENCES}

[1] World Health Organization. Hepatitis B fact sheet NO 204. [Internet] 2015. [cited on 2015 December 26]. Available from: http:// www.who.int/mediacentre/ factsheet/fs204/cn/

[2] World Health Organization (WHO). Guidelines for the screening, care and treatment of persons with chronic hepatitis $\mathrm{C}$ infection. [Internet] 2016. [updated on 2016 April; cited on 2017 February 6]. Available from:

http://apps.who.int/iris/bitstream/10665/205035/1/9789241549615_en g.pdf?ua $=1$

[3] Han L, Zhang HW, Xie JX, Zhang Q, Wang HY, Cao GW. A metaanalysis of lamivudine for interruption of mother-to-child transmission of hepatitis B virus. World J Gastroenterol. 2011; 17: 4321-4333.
[4] WHO. Hepatitis B. [Internet] [cited on 2014 October 22]. Available from: http://www.who.int/mediacentre/factsheets/fs204/en/.

[5] Hwang EW, Cheung R. Global epidemiology of hepatitis B virus infection. N A J Med Sci. 2011; 4(1): 7-13.

[6] Arfaoui D, Fkih M, Hafsa AE, Kaabia N, Azzouz M. Hepatitis B and pregnancy. Tunis Med. 2010; 88: 383-389

[7] Dionne-Odom J, Mbah R, Rembert NJ, Tancho S, Halle-Ekane GE, Enah C, et al. Hepatitis B, HIV, and syphilis seroprevalence in pregnant women and blood donors in cameroon. hindawi publishing corporation. Infectious Diseases in Obstetrics and Gynecology. 2016; 2016.

[8] Beasley RP, Trepo C, Stevens CE, Szmuness W. The e antigen and vertical transmission of hepatitis B surface antigen. Am J Epidemiol. 1977; 105(2): 94-8.

[9] Okada K, Kamiyama I, Inomata M, Imai M, Miyakawa Y. Antigen and anti-e in the serum of asymptomatic carrier mothers as indicators of positive and negative transmission of hepatitis B virus to their infants. N Engl J Med. 1976; 294(14): 746-9.

[10] Keane E, Funk AL, Shimakawa Y. Systematic review with metaanalysis: the risk of mother-to-child transmission of hepatitis B virus infection in sub-Saharan Africa. Aliment Pharmacol Ther. 2016; 44(10): 1005-1017.

[11] Machaira M, Papaevangelou V, Vouloumanou EK, Tansarli GS, Falagas ME. Hepatitis B vaccine alone or with hepatitis B immunoglobulin in neonates of $\mathrm{HBsAg}+/ \mathrm{HBeAg}-$ mothers:a systematic review and meta-analysis. $J$ Antimicrob Chemother. 2015; 70: 396-404.

[12] Lee C, Gong Y, Brok J, Boxall EH, Gluud C. Hepatitis B immunisation for newborn infants of hepatitis B surface antigen-positive mothers. Cochrane Database Syst Rev.2006; 2: 004790.

[13] Brown RS Jr, McMahon BJ, Lok AS, Wong JB, Ahmed AT, Mouchli MA, et al. Antiviral therapy in chronic hepatitis B viral infection during pregnancy: A systematic review and meta-analysis. Hepatology. 2016; 63: 319-33.

[14] Mast EE, Margolis HS, Fiore AE, Alter MJ, Bell BP, Finelli L, et al. A comprehensive immunization strategy to eliminate transmission of hepatitis B virus infection in the United States: recommendations of the Advisory Committee on Immunization Practices (ACIP) part1: immunization of infants, children, and adolescents. MMWR Recommendations and Reports. 2005; 54(RR16): 1-23.

[15] Chen L, Liu F, Fan X, Gao J, Chen N, Wong T, et al. Detection of hepatitis B surface antigen, hepatitis B core antigen, and hepatitis B virus DNA in parotid tissues. Int $J$ Infect Dis. 2009; 13: 20-3.

[16] Esan A, Omisakin C, Ojo-Bola T, Owoseni M, Fasakin K, Ogunleye A. Seroprevalence of Hepatitis B and Hepatitis C Virus Co-Infection among Pregnant Women in Nigeria. American Journal of Biomedical Research. 2014; 2(1): 11-15.

[17] Noubiap JJ, Nansseu JR, Ndoula ST, Bigna JJ, Jingi AM, Fokom DJ. Prevalence, infectivity and correlates of hepatitis B virus infection among pregnant women in a rural district of the Far North Region of Cameroon. BMC Public Health. 2015; 2: 15.

[18] Frambo AA, Atashili J, Fon PN, Ndumbe PM. Prevalence of HBsAg and knowledge about hepatitis B in pregnancy in the Buea Health District. Cameroon: a cross-sectional study. BMC Res Notes. 2014; 7: 394.

[19] Fomulu NJ, Morfaw FL, Torimiro JN, Nana P, Koh MV, William T. Prevalence, correlates and pattern of hepatitis B among antenatal clinic attenders in Yaounde-Cameroon: is perinatal transmission of HBV neglected in Cameroon? BMC Pregnancy Childbirth. 2013; 13: 158.

[20] Rubin E, Farber J. The liver and biliary system. Acute viral hepatitis P 721- 729. Pathology 2nd ed. 1994.

[21] Hou J, Liu Z, Gu F. Epidemiology and prevention of hepatitis B virus infection. Int J Med Sci. 2005; 2: 50-7.

[22] World Health Organization. Guidelines for the prevention, care and treatment of persons with chronic hepatitis B infection. Geneva. 2015.

[23] Kfutwah AK, Tejiokem MC, Njouom R. A low proportion of $\mathrm{HBeAg}$ among HBsAg-positive pregnant women with known HIV status could suggest low perinatal transmission of HBV in Cameroon. Virol J. 2012; 9: 62 .

[24] Ducancelle A, Abgueguen P, Birguel J, Mansour W, Pivert A. High endemicity and low molecular diversity of hepatitis B virus infections in pregnant women in a rural district of North Cameroon. PLOS ONE. 2013; 8(11): 80346.

[25] Mansour W, Malick FZ, Sidiya A, Ishagh E, Chekaraou MA, Veillon $\mathrm{P}$, et al. Prevalence, risk factors, and molecular epidemiology of hepatitis B and hepatitis delta virus in pregnant women and in patients I, Mauritania. J Med Virol. 2012; 84 (8): 1186-1198.

[26] Cho Y, Bonsu G, Ampaw AA, Mills GN, Nimo JA, Park JK, et al. The Prevalence and Risk Factors for Hepatitis B Surface Ag Positivity in Pregnant Women in Eastern Region of Ghana. Gut and Liver J. 2012; 6(2): $235-240$ 
[27] Getnet G, Fikadu W, Almaz A, Kihinetu G. Risk factors associated with hepatitis B virus infection among pregnant women attending antenatal clinic at Felegehiwot referral hospital, Northwest Ethiopia, 2018: an institution based cross sectional study. BMC Res Notes. 2019; 12: 509 .

[28] Umare A, Seyoum B, Gobena T, Haile Mariyam T. HepatitisB Virus Infections and Associated Factors among Pregnant Women AttendingAntenatal Care Clinic at Deder Hospital, Eastern Ethiopia. PLoS ONE. 2016; 11(11): e0166936.

[29] Abongwa LE, Clara AM, Edouard NA, Ngum NH. Sero-Prevalence of Human Immunodeficiency Virus (HIV) and Hepatitis B Virus (HBV) Co-Infection among Pregnant Women Residing in Bamenda Health District, Cameroon. Int. J. Curr. Microbiol. App. Sci. 2015; 4(12): $473-$ 483.

[30] Manyahi J, Msigwa Y, Mhimbira F, Majigo M,. High sero-prevalence of hepatitis B virus and human immunodeficiency virus infections among pregnant women attending antenatal clinic at Temeke municipal health facilities, Dar es Salaam, Tanzania: a cross sectional study. BMC Pregnancy and Childbirth. 2017; 17: 109.

[31] Bayo P, Ochola E, Oleo C, Mwaka AD. High prevalence of hepatitis B virus infection among pregnant women attending antenatal care: a cross-sectional study in two hospitals in northern Uganda. BMJ Open. 2014; 4: e005889.

[32] Tegegne D, Desta K, Tegbaru B, Tilahun T. Seroprevalence and transmission of Hepatitis B virus among delivering women and their new born in selected health facilities, Addis Ababa, Ethiopia: a cross sectional study. BMC Res Notes. 2014; 7: 239.

[33] Baye G, Mohammed S, Abate A. Sero-prevalence of HBV and HCV Infections Among Pregnant Women Attending Antenatal Care Clinic at Dessie Referral Hospital, Ethiopia. Advances in Life Sciences and Health. 2014, 1(2): 109-120.

[34] Zenebe Z, Mulu W, Yimer M, Abera B. Sero-prevalence and risk factors of hepatitis $B$ virus and human immunodeficiency virus infection among pregnant women in Bahir Dar city, Northwest Ethiopia. BMC Infec Dis. 2014; 14: 118. 